\title{
Bokessay: Ann Hs nedtegnelser til allmennheten
}

\author{
Ved Kari Wille Rekdal
}

\section{Angsten eter sjelen}

Ångest, ångest är min arvedel, min strupes sår, mitt hjärtas skri $i$ världen, skrev Pär Lagerkvist i 1916, midt under en pågående verdenskrig, i innledningsdiktet til samlingen Ångest. Knapt hundre år senere sitter Ann Heberlein på venteværelset til det psykiatriske mottaket på St. Lars i Lund og vil bare gågågågå bort fra seg selv og angsten sin, og jeg klarer ikke la være å tenke på Lagerkvists tekst når jeg leser Heberleins Jeg vil ikke $\mathrm{d} \phi$, jeg vil bare ikke leve. Hennes angst er så sterk, smerten så intens at jeg nesten hører Heberleins hjertes skrik i verden. Men Ann Heberleins angst tilhører ikke den chice, eksistensielle kultursjangeren, (den) ... kryper på alle fire og slår hodet $i$ gulvet. Det er ingenting som er kokett eller kult i Heberleins angst. Gjennom teksten sin greier hun om ikke å forklare, så i hvert fall å formidle kraften i angsten og smerten og det uutholdelige i dem.

Kombinasjonen av lidelsestrykket fra den bipolare angsten og fagpersonen som er vant til å uttrykke seg skriftlig gjennom faget sitt, gir både patos og etos når hun skriver om angsten hun opplever og ønsket om å komme bort fra alt sammen. Jeg vil ikke d $\phi$ har solgt i nesten 100000 i hjemlandet Sverige, og skapte enorm oppmerksomhet da den kom ut i 2009. To år senere kom oppfølgeren, boken som på norsk har fått tittelen Et godt liv. Rett f $\varnothing \mathrm{r}$ Jeg vil ikke d $\phi$ hadde hun utgitt boken Det var ikke min skyld!

Kunsten å ta ansvar, en bok som bidro til å gjøre henne til en offentlig person i Sverige. Mellom de to "selvbiografiske" bøkene som omtales her, kom En liten bok om ondskap.

\section{Tilværelsens uutholdelige smerte}

Heberlein har en bipolar lidelse, og i Jeg vil ikke $d \phi$ forteller hun om venterommet på St. Lars i Lund der hun har sittet så mange ganger, fra hun var selvskadende tenåring og til hun nå som nesten førtiårig gift trebarnsmor med doktorgrad fortsatt tyr dit. Venterommet på St. Lars er fyrtårnet i livet hennes: Når ingen kan hjelpe henne, når det ikke er noen hun kan ringe, da har hun St. Lars. Store deler av teksten belyser fra ulike vinkler det som er Heberleins store problem: ... en ekte filosofisk apori, et uløselig filosofisk dilemma, $i$ seg selv en angstskapende situasjon ... Det er ikke det at Heberlein vil $\mathrm{d} \varnothing$, hun vil bare ikke leve. Men hun mener at hun har en plikt til å leve fordi hun er mor til tre barn. Jeg kan ikke forlate barna mine. Jeg elsker barna mine. Men virkeligheten viser, som både Heberlein og vi vet, at mange foreldre faktisk forlater barna sine, til tross for at de elsker dem slik Heberlein elsker sine, eller kanskje nettopp derfor? Kanskje er det lettere å leve i en følelse av mislykkethet, eller lettere å unngå følelsen av mislykkethet, av å komme til kort, når man ikke elsker noen så høyt, kanskje er graden av styrke i kjærligheten motsvarende styrken i motløsheten og fortvilelsen?

Etter å ha snakket med en lege, fått tabletter og avslått et tilbud om innleggelse, setter Heberlein seg i bilen og kjører av sted for å ta livet sitt. Denne gangen orker hun ikke mer, hun er så sliten, så fryktelig sliten av å kjempe mot angsten, kjempe for å holde seg fast i livet, kjempe for å forsvare at hun ikke makter å sette pris på det hun faktisk har. Alt er ordnet og gjort klart; hjemme har barna fått nye klær så de ikke skal mangle noe, hun har forberedt skolestart for alle tre, hun har klargjort en tekst hun skal sende til mannen sin slik at han forstår hvorfor hun må gjøre dette, teksten til denne boken skal hun straks sende til sin egen e-post, som mannen har fått passordet til. Nei, hun lengter ikke etter å d $\varnothing$, det er livet hun ikke greier, skriver hun. Heberleins filosofiske dilemma er i ferd med å finne sin løsning. For oss lesere er det ikke lett å forstå at den kjærligheten til barna som kommer så sterkt frem i det hun skriver, ikke skal være tilstrekkelig til å holde på henne, holde henne i verden nettopp for og hos barna. Men angsten og smerten er sterkere, kanskje også selvforakten fordi hun ikke makter. I det store og hele er kjærligheten til barna sterkere enn angsten min, men ikke i hvert enkelt øyeblikk. Da tenker hun at verden ville være bedre uten henne, at barna hennes ville ha det bedre uten henne.
Ann Heberlein: Jeg vil ikke $\mathrm{d} \phi$, jeg vil bare ikke leve (oversatt av Astrid Nordang). Cappelen Damm 2009, 179 s. ISBN: 9788-2023-32-457

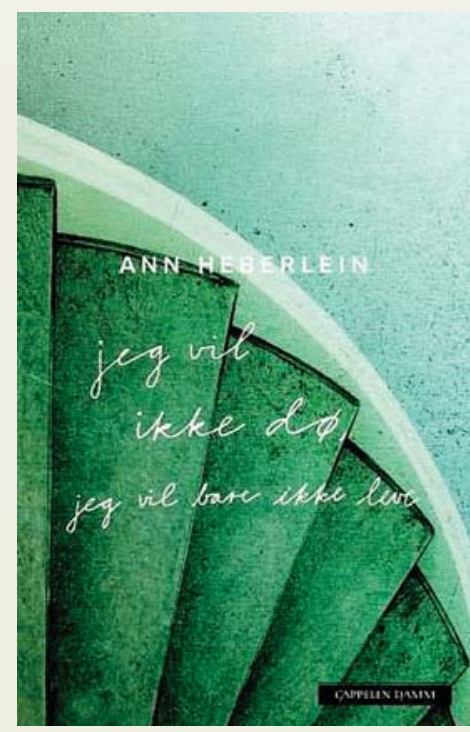

Ann Heberlein: Et godt liv (oversatt av Tron Furu).

Cappelen Damm 2012, 212 s. ISBN: 9788-2023-56-217
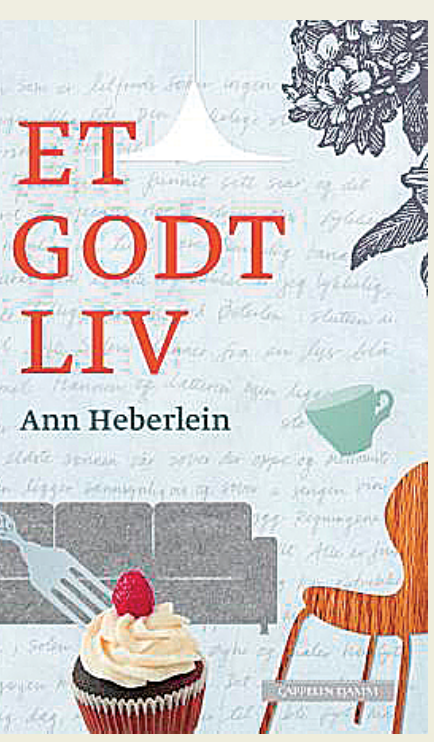
Heberlein har vært i Norge mange ganger, selv traff jeg henne under et arrangement LEVE hadde på Litteraturhuset i Oslo i forbindelse med Verdensdagen for selvmordsforebygging i 2011. I sesjonen før hun skulle på scenen, hadde jeg en litteratursamtale med forfatter og VG-journalist Guro Hoftun Gjestad, og da brukte jeg en formulering som jeg ofte bruker i sånne sammenhenger, om at vi som har opplevd at noen vi er glad $i$ velger bort livet og oss og fremtiden vår sammen. Heberlein grep fatt i dette da hun kom på scenen og presiserte at det var ikke sånn det var, at man valgte bort noen, at det var rettet mot andre. Det var bare det at hun ikke klarte å være i livet og angsten, derfor $\varnothing$ nsket hun seg bort slik at barna hennes skulle få det bedre, hun valgte ikke barna bort. Og det er jo sant fra hennes ståsted, det er slik det ser ut fra innsiden hos henne, hun velger ikke bort barna sine og mannen sin og familien og vennene. Men fra innsiden hos meg (og andre etterlatte) ser det akkurat slik ut: Den som har tatt livet sitt, har valgt oss bort, som aktiv handling. Bare betegnelsen "etterlatt" - noen har gått sin vei og latt oss være tilbake. Forskjellen i synsvinkel er avgjørende for fortolkning og forståelse - hvis mentalisering er det å kunne forstå seg selv fra utsiden og andre fra innsiden, så er det kanskje sånn at noe av det som forsvinner for et selvmordsnært menneske nettopp er evnen til å mentalisere? Det finnes ingen enkle og entydige forklaringer på selvmord, og alle selvmord er heller ikke like. Men det slår meg at her er det på den ene siden så enormt mye omtanke for de nærmeste, og på den andre siden en sånn mangel på forståelse for hvordan livet vil bli for dem etterpå, at det kanskje kan ligge noe her, et spor på veien til en forståelse? Eller er det bare symptomene jeg ser, ikke selve sykdommen?

\section{Døden ikke heller}

Heberlein vil ikke $d \varnothing$, det er angsten som er hennes store problem, som gjør livet uutholdelig for henne og som driver henne. Angsten er skambelagt, den viser henne hvor verdiløs hun er. Angsten min kjører bil veldigveldigveldig fort hele veien fra Malmö til Stockholm (...) Angsten min er stygg og lukter ille og den må gjemmes bort. Selvmordet, som hun egentlig ikke $\varnothing$ nsker, blir løsningen. Hun diskuterer selvmord som etisk valg og som del av menneskets autonomi. Har individet rett til å giøre det valget, også når det er et dumt valg? Hun trekker frem Améry, Burger og Kamlah som argumenterer for retten til å få avslutte eget liv når man selv $\varnothing$ nsker det. Selv er hun ... grenseløst takknemlig over at jeg ikke er død. Hun argumenterer ikke for retten til å få ta sitt eget liv: Jeg argumenterer for retten til mitt liv. De dagene angsten og livsleden er sterkere enn kjærligheten til mine barn, må en annen tre inn og være min vilje, den viljen til a leve som tilfeldigvis har forlatt meg. Og allikevel sier hun nei til tilbudet om å bli innlagt på St. Lars, setter seg i stedet i bilen for å kjøre til Ørnehusene og ta livet sitt der. Vil, og vil ikke. Det ville jo ikke vært noe problem om det ikke fantes en viss grad av ambivalens $i$ hele den livstrøtthetsgreia.

\section{To tunger har mitt hjerte}

Dualiteten i bokens tittel tematiseres gjennom hele boken, blant annet slik det vises til i foregående avsnitt. Sånn sett er hele teksten bipolar. Heberlein vil verken $\mathrm{d} \varnothing$ eller leve, noe som faktisk ikke lar seg gjøre. Denne problemstillingen speiler forfatterens diagnose, sinnstilstanden som veksler mellom det mulige og det umulige. Et annet spørsmål forfatteren kretser rundt, er Hvem kan man ringe til? ... Hva kan man kreve som venn? Hvor går grensen? Venner, ektefeller, ekskjærester, slektninger - når livet er som verst, er det ingen hun føler hun kan ringe til. Hvem ringer man når man ikke orker å leve? Men når hun slår på telefonen igjen etter å ha snakket med en lege på St. Lars, er den full av meldinger og tapte anrop. Igjen denne dobbeltheten: ingen å ringe til, samtidig som det ringer hele tiden.

\section{Men livet lever}

Heberlein tok ikke livet sitt slik hun planlegger i Jeg vil ikke d $\phi$. I Et godt liv tar hun utgangspunkt $i$ en behandlingstime der psykiateren hennes forteller henne at nå er hun frisk, og burde hun ikke tenke på å skrive en bok om å bli frisk? Og så gjør hun det; boken har psykiaterens spørsmål som utgangspunkt og sluttpunkt, den begynner og slutter med hans uttalelse.

Et godt liv er i tre deler, hver av delene er igjen inndelt i underkapitler som innledes med små definisjoner fra Nationalencyklopedin av det ordet som er underkapitlets tema; temaene spenner vidt fra sykdom og desperasjon til Guds rike, politikk, autoritet, frihet, moral, determinisme osv. Jeg kjenner at det er et grep jeg liker enormt godt, det er pedagogisk og praktisk og fremhever underveis det hun tar utgangspunkt i. Boken er ellers veldig løst strukturert, det er Heberleins tanker og følelser og reaksjoner som formidles til oss, om livet, men også veldig mye om reaksjonene på Jeg vil ikke $\mathrm{d} \phi$, og om hennes reaksjoner på reaksjonene.

Når jeg leser disse to bøkene, tenker jeg at Heberlein vet mer om ikke å ville leve enn om hva som er et godt liv. Der Jeg vil ikke $d \phi$ har både et intenst nærvær og en vilje til selvutlevering av nesten knausgårdske dimensjoner, er Et godt liv flatere, uengasjerende, mer skravlete, ikke alltid like gjennomtenkt. Eksempelvis skriver hun: $\AA$ være syk er a mangle evnen til å leve et godt liv, det gjelder både kreftpasienten og den psykisk syke. Men utsagnet sier oss ikke noe særlig mer om hva et godt liv er. Er det umulig for en syk person å leve et godt liv? Det tror jeg det finnes mennesker som vil protestere på. En kreftpasient som synes hun har et godt liv, er hun ikke syk? Hva som utgiør et godt liv, er ingen objektiv st $\varnothing$ rrelse, vi har alle ulike forventninger og $\varnothing$ nsker til livet, men jeg får ikke tak i så veldig mye om hva som er et godt liv for Heberlein. Hun er innom galskap/normalitet hos Foucault og Lacan, men som teolog med doktoravhandling om etikk kunne hun i st $\varnothing$ rre grad brukt ulike fagtilnærminger for å diskutere begrepet ved siden av sine egne oppfatninger. Jeg leser Et godt liv som en naturlig oppfølger til Jeg vil ikke d $\phi$, det er vanskelig å tenke seg førstnevnte hvis ikke Jeg vil ikke $\mathbf{d} \phi$ hadde kommet ut, men den står ikke helt på egne ben som selvstendig verk om Livet. 


\section{Meg eier ingen}

I store deler av Et godt liv skriver Heberlein om opplevelsen av at noen har overtatt livet hennes, at vi andre vet for mye om henne etter utgivelsen av Jeg vil ikke $\mathrm{d} \phi$, og om reaksjonene på denne opplevelsen. Til tross for at Heberlein var kulturskribent og debattant i offentligheten $f \varnothing r$ Jeg vil ikke d $\phi$ kom ut, var hun helt uforberedt på debatten den skapte, og omfanget av oppmerksomheten boken og hun fikk. Det minner om den type magi vi kan finne i enkelte kulturer der noen nekter å la seg fotografere fordi å bli tatt bilde av kan innebære at andre overtar sjelen til den fotograferte, eller om troen på voodoo-dukker. Faktisk finnes det moderne forskning hvor studier viser at vi fortsatt tenker i slike magiske baner; the image equals the object. I vårt tilfelle er Jeg vil ikke $\mathrm{d} \phi$ bildet som tilsvarer objektet Heberlein; leserne, omgivelsene, samfunnet setter likhetstegn mellom boken og personen, og selv føler hun avmakt og tap av kontroll. Heberlein vil ta tilbake makten nå, og kontrollen over bildet sitt, det prøver hun å gjøre gjennom teksten.

\section{Det var ikke min skyld - om kunsten å ta ansvar}

Som nevnt synes jeg ikke at Et godt liv sier så veldig mye om hva som er eller kan være et godt liv. I min lesning handler den mer om å ta avstand; fra selvutleveringen, fra den andre Ann, fra bokens forlegger som får skylden for å ha manipulert henne utpå glattisen ved å skrive og utgi og markedsføre Jeg vil ikke d $\phi$ på den måten som det ble gjort. Det er åpenbart at mottakelsen av boken og debattene den skapte, sammenstilt med medias bruk av Heberleins person, ble veldig t $\varnothing \mathrm{ft}$ for henne. Burde ikke et erfarent bokmenneske, en fagperson, en reflektert person ha forstått på forhånd hva Jeg vil ikke $\mathrm{d} \phi$ kunne innebære når den kom ut? Ann i Et godt liv er så opptatt av å ta avstand fra "Ann" i Jeg vil ikke d $\phi$; det synes jeg absolutt ikke at hun fortjener. Jeg blir lei meg på “Ann”'s vegne, vi ble liksom ganske godt kjent, synes jeg, i Jeg vil ikke d $\phi$.
Ann Heberlein i bok nummer to vil ikke helt vite av Ann Heberlein i bok nummer én, hun omtaler henne også som hun, jeg, Ann Heberlein. Heller enn et fors $\varnothing \mathrm{k}$ på å finne ut hva et godt liv er eller kan være, leser jeg boken som en apologi for Jeg vil ikke d $\boldsymbol{\phi}$, det var ikke Heberleins skyld at boken kom ut, at den ble som den ble. Forventningene hos oss som først har lest Jeg vil ikke $\mathrm{d} \phi$, blir ikke oppfylt av at Et godt liv handler så mye om ansvarsfraskrivelse, det ville vært mye mer interessant å få vite mer om livet og synspunkter på hva som kan være bra fra henne som verken ville $\mathrm{d} \varnothing$ eller leve.

\section{Har vi henne nå?}

Hva kan vi egentlig vite om Heberlein etter å ha lest disse to bøkene? Hvem av dem er henne? Og er man diagnosen sin? Dette er interessante spørsmål som vi kan søke å finne svar på etter å ha lest Heberleins tekster. Jeg skal streife innom dem så vidt. $\AA$ se de to bøkene i sammenheng: Jeg har tidligere i dette essayet nevnt at jeg leser Et godt liv som en apologi for Jeg vil ikke d $\phi$, alternativt kan den leses som en pendant til Jeg vil ikke d $\phi$, som en tekst som utvider og fortolker fortellingen i den første boken. De to bøkene kan også sees som bilde på de to polene i diagnosen til forfatteren, fortellerstemmen i bøkene som to forskjellige sider av forfatteren og som representanter for hver sin side av sykdommen.

I likhet med mange andre svensker i tiden etter andre verdenskrig har Heberlein foretatt en klassereise, fra arbeiderklasseoppvekst til middelklassevoksenliv. Ting og status betyr mye for henne, det er viktig for henne å vite at barna, og da særlig datteren, vokser opp uten å savne materielle goder, at de făr oppleve reiser til utlandet, at de får den selvtilliten som en middelklassebakgrunn gir ikke inn med morsmelken, for til sin store sorg, skriver Heberlein, har hun ikke kunnet amme barna sine, tross den store kjærligheten hun har til dem som en naturlig del av å vokse opp der de bor, i den slags leilighet eller hus som familien gjennom sitt middelklasseliv aspirerer til. Det bidrar på den ene siden til å gjøre Heberlein menneskelig og gjenkjennelig for oss, dette at hun i likhet med mange andre mennesker er så opptatt av ting og status, samtidig synes jeg det er skuffende - hun er liksom den stilige dama jeg er blitt kjent med, modig og tøff og flink og kul, og så finnes det en liten sosial streber inni der. Men det at hun ikke er redd for å vise oss sin sårbarhet, sine svake sider, sin tvil og sin usikkerhet, er allikevel en stor del av styrken i teksten.

\section{Life - but how to live it}

Livet er vanskelig og vakkert og stort og mangfoldig.

Jeg ville ikke vært Jeg vil ikke d $\phi$ foruten, boken er sterk og sår og viktig, og alle som er interessert i de mer smertefulle og mørke sidene av livet, enten det er for å forstå seg selv eller andre eller bare for å søke å oppnå $\varnothing \mathrm{kt}$ innsikt, bør definitivt lese den. I tillegg til den sterke egenopplevelsen tematiserer den viktige spørsmål om livet, om valg vi har, og om hvordan det er å leve med en diagnose. Et godt liv er jeg ikke så sikker på, av grunner som jeg har vært tilstrekkelig inne på tidligere i teksten, den er en bok som ikke greier å overbevise om sin rett til egeneksistens. Jeg vil ikke d $\phi$ står derimot fjellst $\varnothing$ tt på egne angstfylte ben. Det er ikke n $\varnothing$ dvendig for forståelsen av den å lese Et godt liv, men for de av dere som er tilhengere av historisk-biografisk lesning av bøker, fungerer Et godt liv som bonusspor.

Et bitte lite hjertesukk, Cappelen Damm: Det må da være mulig å finne noen i det store forlagshuset deres som har kunnskap om de norske kommareglene?

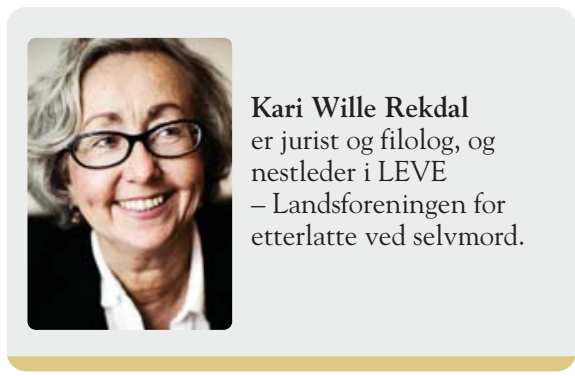

